\title{
Assessment and comparison of the effects of two techniques on hamstring flexibility ${ }^{1}$
}

\author{
Avaliação e comparação dos efeitos de duas técnicas de \\ alongamento na flexibilidade dos músculos isquiotibiais
}

\section{Marcelo Tavella Navega ${ }^{[a]}$, Bruna Paleari ${ }^{[b]}$, Mary Hellen Morcelli ${ }^{[c]}$}

[a] PhD, professor, Universidade Estadual Paulista Júlio de Mesquita Filho (Unesp), Departamento de Fisioterapia e Terapia Ocupacional, Marília, SP - Brazil, e-mail: navega@marilia.unesp.br

[b] Undergraduate student, Universidade Estadual Paulista Júlio de Mesquita Filho (Unesp), Departamento de Fisioterapia e Terapia Ocupacional, Marília, SP - Brazil, e-mail: bruna.paleari@yahoo.com.br

[c] PhD student, Universidade Estadual Paulista (Unesp), Rio Claro, SP - Brazil, e-mail: mary_morcelli@yahoo.com.br

\begin{abstract}
Introduction: There are several stretching techniques that help increase flexibility, however, there are still questions regarding which method leads to the most effective gains. Objectives: To assess and compare the effects of two stretching techniques, namely proprioceptive neuromuscular facilitation (PNF) and static stretching on the flexibility of hamstring muscles of young women. Methods: The study sample consisted of 45 young women, mean age $20.45( \pm 1.66)$,assigned to one of three groups: static stretching group (SSG, $\mathrm{n}=15$ ), proprioceptive neuromuscular facilitation group (PNFG, $\mathrm{n}=15$ ) and control group (CG, $\mathrm{n}=15$ ). Both SSG and PNFG carried out three weekly stretching sessions over a four-week period. The sit and reach and popliteal angle tests were used at the beginning and end of the intervention. Normally distributed data were analyzed using Student's t-test, whereas data with non-normal distribution were analyzed using the Wilcoxon test, to compare initial and end measurements for each technique. Finally, we used the Mann-Whitney U test to compare both techniques with each other. A significance level of $5 \%(p<0.05)$ was

\footnotetext{
${ }^{1}$ Financial support: Conselho Nacional de Desenvolvimento Científico e Tecnológico (CNPq). Ethics Committee Resolution: $0097 / 2011$.
} 
adopted. Results: There was a significant increase in hamstring flexibility when analyzing the assessments and reassessments of both stretching protocols. Conclusions: Both techniques were effective in increasing hamstring flexibility and there were no significant differences to indicate which one is better in increasing the flexibility of this muscle group.

Keywords: Stretching. Hamstrings. Flexibility. Women. Physical Therapy.

\section{Resumo}

Introdução: Existem diversas técnicas de alongamento que auxiliam o aumento de flexibilidade, entretanto ainda prevalecem dúvidas sobre qual método aponte ganhos majoritariamente eficazes. Objetivos: Avaliar e comparar os efeitos das técnicas de alongamento Facilitação Neuromuscular Proprioceptiva (FNP) e o Alongamento Estático na flexibilidade dos músculos isquiotibiais de jovens mulheres. Métodos: Participaram do estudo 45 jovens, mulheres, com média de idade entre 20,45 $( \pm 1,66)$, que foram divididas em três grupos: grupo alongamento estático (GAE, $n=15)$, grupo alongamento facilitação neuromuscular proprioceptiva (GFNP, $n=15)$ e grupo controle (GC, $n=15)$. Os grupos GAE e GNFP realizaram três sessões semanais de alongamento durante quatro semanas. As voluntárias foram avaliadas por meio do Teste Sentar e alcançar e pelo Teste do Ângulo poplíteo no início e ao fim das intervenções. Os dados com distribuição normal foram analisados pelo Teste t de student, para os dados com distribuição não normal, foi utilizado o Teste de Wilcoxon para comparar cada técnica e o Teste de Mann-whitney para comprar as duas técnicas. Foi adotado o nível de significância de 5\% ( $p$ <0,05). Resultados: Houve aumento significativo da flexibilidade dos músculos isquiotibiais quando analisadas as avaliações e reavaliações em ambos os protocolos de alongamento. Conclusões: Ambas as técnicas são eficazes para o ganho de flexibilidade dos músculos isquiotibiais, não apresentando diferenças significativas que evidenciasse qual delas é a melhor para o ganho de flexibilidade desse grupo muscular.

Palavras-chave: Alongamento. Isquiotibiais. Flexibilidade. Mulheres. Fisioterapia.

\section{Introduction}

Physical exercise is an essential factor for improving quality of life (1). Thus, when performed regularly and under the guidance of a specialized professional, it brings about numerous benefits $(2,3,4)$. However, when conducted incorrectly, physical exercise can lead to injuries (5). Therefore, specific therapeutic maneuvers, such as stretching, are important for preparing a person's physical condition before exercising (6).

Stretching favors soft tissue mobility by increasing the number of sarcomeres in series and thus increasing muscle length and range of motion $(6,7)$. In addition to these effects, stretching also aids in posture training and is a form of improving muscle flexibility (8).

Greater flexibility contributes to preventing injuries, posture alterations, lower back pain (8) and helps improve muscular performance (9). On the other hand, loss of flexibility results in a limited ability of the muscle-tendon units to deform, which hinders posture, muscular performance and limits range of motion $(10,11)$. Reduced flexibility is one of the risk factors for muscle injuries (7).

The most common muscle injury are sprains, which can occur due to hamstring tightness (12), and prevent athletes from carrying on their sports activities (8). Thus, adequate stretching programs are essential for improving flexibility and preventing injuries $(13,14)$.

Several stretching techniques have been developed (6), and the main ones found in the literature are passive or static stretching and proprioceptive neuromuscular facilitation (PNF), also known as the tense-relax technique $(6,15)$.

Although there are many stretching techniques that help increase flexibility, there are still questions regarding which method leads to the most effective gains (14). One study suggested that proprioceptive neuromuscular facilitation (PNF) was more effective in increasing hamstring flexibility than static stretching 
(14). On the other hand, another study indicated that static stretching might be the only method capable of maintaining significant gain in hamstring muscle range of motion for up to 24 hours (16). Furthermore, some parameters related to stretching maneuvers have generated questions regarding their applicability, such as frequency, number of repetitions, duration time and intensity of stretches (17).

In light of these controversies and because of the common nature of hamstring injuries, this study was dedicated to investigating which technique would be the most effective for stretching hamstring muscles. Thus, the objective of the current study was to assess and compare the effects of the proprioceptive neuromuscular facilitation (PNF) technique and static stretching on the hamstrings of young women.

\section{Methods}

\section{Ethical aspects}

The present study was approved by the local human research ethics committee, under protocol number0097/2011. All the women gave written informed consent and received orientation pertinent to the study.

\section{Subjects}

Participants comprised 45 young women from 18 to 28 years, assigned to one of three groups: static stretching group (SSG, $\mathrm{n}=15$ ), proprioceptive neuromuscular facilitation group (PNFG, $\mathrm{n}=15$ ) and control group ( $C G, n=15)$. Sample characteristics are presented in Table 1.
Exclusion criteria for this study were: having sustained a hamstring injury in the past three months, having used pain medication in the past two weeks and carried out lower limb stretching or muscle strengthening sessions over the past three months.

\section{Procedures}

Flexibility was measured using two assessment tools: the sit and reach test and the popliteal angle test. Volunteers were first assessed individually, which was followed by specific stretching protocols. Stretching was conducted in the SSG and PNFG groups, three days a week for four consecutive weeks. Stretching tests and procedures were all conducted on the same days of the week and at the same time, according to the time of day of the first session. When participants reported discomfort (stretching sensation), they were considered to be at the maximum stretching point.

After the protocol, volunteers were reassessed, and a three-day interval was established between sessions. Stretching maneuvers and assessments were conducted on both lower limbs.

\section{Sit and Reach Test}

Volunteers sat on the floor with their legs fully extended, their hips flexed at $90^{\circ}$ and the bottom of their feet against the Wells test box. With arms extended and hands facing down, volunteers leaned forward at thehips and attempted to push the marker on the ruler as much as possible, while keeping knees straight. The test was conducted three times, and the highest measurement value was used as data $(17,18)$.

Table 1 - Sample characteristics

\begin{tabular}{lccc}
\hline & $\begin{array}{c}\text { Static Group } \\
(\mathbf{n}=\mathbf{1 5})\end{array}$ & $\begin{array}{c}\text { PNF Group } \\
(\mathbf{n}=15)\end{array}$ & $\begin{array}{c}\text { Control Group } \\
(\mathbf{n}=15)\end{array}$ \\
\hline Age (years) & $20.8 \pm 1.20$ & $20.5 \pm 1.64$ & $20.1 \pm 2.06$ \\
Weight (kg) & $58.7 \pm 8.94$ & $58.9 \pm 8.41$ & $59.2 \pm 10.24$ \\
Height (m) & $1.61 \pm 0.05$ & $1.64 \pm 0.06$ & $1.64 \pm 0.07$ \\
BMI (kg/m) & $22.5 \pm 2.58$ & $21.6 \pm 2.96$ & $21.7 \pm 3.51$ \\
\hline
\end{tabular}

Note: $\mathrm{BMI}=$ body mass index. 


\section{Popliteal Angle Test}

With volunteers in supine position, the assessed limb was flexed at the hip and knee with the help of a goniometer. Test-leg hip was flexed to $90^{\circ}$ throughout the test with the help of a wooden plank. Contralateral leg remained completely extended. A photograph was taken of the initial position, with the camera positioned two meters away from the volunteer. After this procedure, the evaluator asked the woman to extend her knee as much as possible, when another photograph was taken.

Photographs were digitalized for analysis using AutoCAD ${ }^{\circledR}$ software. Three anatomical reference points were marked on the volunteers' lower limbs using marking tape. Two lines were drawn, one connecting the greater trochanter of the femur to the head of the fibula and another line connecting the lateral malleolus to the head of the fibula. The software measured the angle formed by these two lines, called the popliteal angle (19).

\section{Static Stretching Protocol}

The volunteer was supine, and the evaluator conducted a maximum passive hip flexion, keeping the knee completely extended. The stretching protocol consisted of five thirty-second cyclesin this position. Between cycles, there was a 30-second rest interval. The contralateral limb remained stabilized and completely extended. In addition, between cycles, volunteers were asked for consent to increase hip flexion $(15,20)$.

\section{Proprioceptive Neuromuscular Facilitation Stretching Protocol}

Volunteers were placed in supine position. Hips were passively flexed by the evaluator and the knee remained completely extended until reaching maximum hip flexion. The contralateral limb remained stabilized and completely extended. Five seconds of isometric contraction were conducted followed by ten more seconds of stretching with the muscles relaxed. This process was repeated twice and the maneuver lasted 30 seconds. The technique was conducted for five 30-second cycles, with a 30-second rest interval between them. During the rest intervals, volunteers were asked for consent to increase hip flexion $(15,20)$.
Statistical analysis

Initially, the Shapiro-Wilk Normality test was applied to verify data distribution. Student's t-test was used to analyzenormally distributed data. The Wilcoxon test was used to analyze non-normal data, i.e., comparisons of initial and final assessments for each technique. Finally, the Mann-Whitney test was used to compare one technique to the other. A $5 \%$ significance level ( $p \leq 0.05)$ was adopted for data interpretation.

\section{Results}

Initial and final assessment data of the sit and reach test for static stretching and PNF groups are illustrated in Table 2.

There was a significant increase in hamstring muscle flexibility in both static stretching and PNF groups. However, no significant differences were observed between techniques. Regarding control group data, there was no significant difference between assessments (initial: $29.27 \pm 6.57$; final: $29.8 \pm 5.60$, $\mathrm{p}=0.481$ ).

Results of the initial and final popliteal angle test for dominant and non-dominant limb for each group are expressed in Tables 3 and 4, respectively. Both static and PNF groups presented increased flexibility (expressed in degrees). Furthermore, a more evident gain was observed in the dominant inferior limb. However, there was no significant difference between techniques.

Regarding the control group, the dominant lower limb presented significant results between assessments (initial: $170.87 \pm 7.26$ and final: $166.73 \pm 10.27$, $\mathrm{p}=0.045$ ), whereas the non-dominant lower limb did not reach significant levels between assessments (initial: $169.67 \pm 8.20$, final: $165.8 \pm 12.29, \mathrm{p}=0.091$ ).

\section{Discussion}

Although there are several stretching techniques that can prevent muscleshortening and consequently lead to increased flexibility, there are still questions regarding which is the most effective method (6). Thus, the present study examined the effects of proprioceptive neuromuscular facilitation (PNF) and static stretching on hamstring flexibility in young women. 
The tests used in this study are of great clinical importance. The popliteal angle test is a method that investigates hamstring muscle flexibility in isolation (19), whereas the sit and reach test assessed the posterior chain as a whole, including hamstrings and other muscles, such as the paravertebrals, gluteus maximus and triceps surae $(21,22)$. A previous study has shown that the popliteal angle test has good reliability when conducted in healthy individuals (23). With respect to the sit and reach test, in addition to presenting good reliability for assessing hamstring flexibility, it is also easy to apply $(24,25)$.

The findings of the present study indicate that both stretching techniques improve hamstring flexibility, as significant differences were found between assessments and reassessments for both techniques separately. In this same context, other studies comparing PNF to other methods showed that PNF led to greater increases in hamstring flexibility (26, 27). In the same way, another study that compared static stretching to other techniques found that this method led to instant flexibility gains (28).

Mallmann et al. (22) compared three stretching techniques, among them static stretching and proprioceptive neuromuscular facilitation, and concluded that stretching led to immediate increased flexibility. Despite the methodological differences, such results corroborate those found in the current study.

Table 2 - Mean and standard deviation values in static stretching and PNF groups obtained at initial and final evaluations after 4 weeks of intervention

\begin{tabular}{lccc}
\hline & \multicolumn{2}{c}{ Sit and Reach Test } & \\
\hline & Initial & Initial & $\mathrm{p}^{*}$ \\
\cline { 2 - 4 } Static Group & Mean $\pm \mathrm{SD}$ & Mean $\pm \mathrm{SD}$ & 0.0007 \\
PNF Group & $27.4 \pm 10.40$ & $27.4 \pm 10.40$ & 0.0007 \\
$\mathbf{p}^{* *}$ & $24.27 \pm 8.46$ & $24.27 \pm 8.46$ & \\
\hline
\end{tabular}

Note: $\mathrm{p}^{*}=$ intragroup comparison; $\mathrm{p}^{* \star}=$ intergroup comparison.

Table 3 - Dominant-limb values expressed in mean and standard deviation

\begin{tabular}{lccc}
\hline \multicolumn{4}{c}{ Popliteal Angle Test - Dominant Lower Limb } \\
\hline & Initial & Final & \\
\cline { 2 - 3 } & Mean \pm SD & Mean \pm SD & \\
Static Group & $165^{\circ} \pm 7.16$ & $173.53^{\circ} \pm 4.47$ & $\mathrm{p}^{*}$ \\
PNF Group & $158.33^{\circ} \pm 10.77$ & $168.4^{0} \pm 9.62$ & 0.0007 \\
$\mathbf{p}^{* *}$ & 0.0649 & 0.1409 & 0.0007 \\
\hline
\end{tabular}

Note: $\mathrm{p}^{\star}=$ intragroup; $\mathrm{p}^{* *}=$ intergroup.

Table 4 - Non-dominant limb values expressed in mean and standard deviation

\begin{tabular}{lccc}
\hline & \multicolumn{2}{c}{ Popliteal Angle Test - Non-Dominant Lower Limb } & \\
\cline { 2 - 4 } & Initial & Final & \\
Mean \pm SD & Mean \pm SD & \\
Static Group & $165.2^{0} \pm 7.48$ & $171.67^{0} \pm 5.67$ & $\mathrm{p}^{*}$ \\
PNF Group & $158.2^{0} \pm 9.81$ & $166^{\circ} \pm 8.70$ & 0.0007 \\
$\mathbf{p}^{* *}$ & 0.0591 & 0.0620 & 0.0007 \\
\hline
\end{tabular}

Note: $\mathrm{p}^{*}=$ intragroup; $\mathrm{p}^{* *}=$ intergroup. 
The present study did not find significant differences to indicate which of the two applied stretching techniques was more efficient in increasing hamstring flexibility. The study showed that both were effective, findings that corroborate those of a previous study that did not find any expressive differences between these two methods (29).

On the other hand, O'Hora et al. (30) compared static stretching with PNF and concluded that the latter displayed better hamstring flexibility results. However, the stretching protocol consisted of one therapy session alone, different from the protocol used in this study.

In addition to the prevailing question that guided this study, i.e., which stretching technique is more effective, other issues generate questions as well, such as the frequency, number of repetitions and duration of stretches.

Each study employed different protocols in the attempt to verify the most effective stretching method $(31,32)$. This study conducted three weekly sessions, which led to increased hamstring flexibility, corroborating the study by Marques et al. (33)that considered this protocol as sufficient for flexibility gain.

Finally, in light of the results found here and in the studies mentioned above, it is clear that the studied techniques are important and effective in increasing flexibility.

\section{Conclusion}

The results of the present study allow for the conclusion that both static stretching and proprioceptive neuromuscular facilitation techniques are effective in increasing hamstring flexibility.

However, on comparing both techniques, there were no significant differences to indicate which one is more effective for increasing flexibility of this muscle group.

\section{Acknowledgements}

The authors thank CNPq for the research grant.

\section{References}

1. Santos ALP, Simões AC. Educação física e qualidade de vida: reflexões e perspectivas. Saude Soc. 2012; 28(1):181-92.
2. Guedes DP, Gonçalves LAVV. Impacto da prática habitual de atividadefísica no perfillipídico de adultos. Arq Bras Endocrinol Metab. 2007;51(1):72-8.

3. Stamatakis E, Hamer M. The extent to which adiposity markers explain the association between sedentary behavior and cardiometabolic risk factors. Obesity (Silver Spring). 2012;20(1):229-32.

4. Warren JM, Ekelund U, Besson H, Mezzani A, Geladas N, Vanhees L. Assessment of physical activity - a review of methodologies with reference to epidemiological research: a report of the exercise physiology section of the European association of cardiovascular prevention and rehabilitation. Eur J Cardiovasc Prev. 2010;17(2):127-39.

5. Pastre CM, Carvalho Filho G, Monteiro HL, Netto Júnior J, Padovani CR. Lesões desportivas na elite do atletismo brasileiro: estudo a partir da morbidade referida. Rev Bras Med Esporte. 2005;11(1):43-7.

6. Di Alencar TAM, Matias KFS. Princípios fisiológicos do aquecimento e alongamento muscular na atividade esportiva. Rev Bras Med Esporte. 2010;16(3):230-4.

7. Brad W. Alongamento: Uma abordagem anatômica. São Paulo: Manole; 2009.

8. O’Sullivan K, Murray E, Sainsbury D. The effect of warm-up, static stretching and dynamic stretching on hamstring flexibility in previously injured subjects. BMC Musculoskelet Disord. 2009;10:37.

9. Shrier I. Does stretching improve performance? A systematic and critical review of the literature. Clin J Sport Med. 2004;14(5):267-73.

10. Bandy WD, Iron JM, Briggler M. The effect of time and frequency of static stretching on flexibility of the hamstring muscles. Phys Ther. 1997;77(10):1090-6.

11. Achour AJ. Bases para os exercícios de alongamento. 2. ed. São Paulo: Phorte Editora; 1999.

12. Hall SJ. Biomecânicabásica. 3. ed. Rio de Janeiro: Guanabara Koogan; 2009.

13. Malliaropoulos N, Papalexadris S, Papalada A, Papacostas E. The role of stretching in rehabilitation of hamstring injuries: 80 athletes follow-up. Med Sci Sports Exerc. 2004;36(5):756-9.

14. Fasen JM, O'Connor AM, Schwartz SL, Watson JO, Plastaras CT, Garvan CW, et al. A randomized controlled trial of hamstring stretching: comparasion of four techniques. J Strength Cond Res. 2009;23(2):660-7. 
15. Gama ZAS, Medeiros CCS, Dantas AVR, Souza TO. Influência da freqüência de alongamento utilizando facilitação neuromuscular proprioceptiva na flexibilidade dos músculos isquiotibiais. Rev Bras Med Esporte. 2007;13(1):33-8.

16. Weijer VC, Gorniak GC, Shamus E. The effect of static stretch and warm-up exercise on hamstring length over the course of 24 Hours. Am J Sports Med. 2003; 33(12):727-33.

17. Chagas MH, Bhering EL, Bergamini JC, Menzel HJ. Comparação de duas diferentes intensidades de alongamento na amplitude de movimento. Rev Bras Med Esporte. 2008;14(2):99-103.

18. Bertolla F, Baroni BM, Leal JECP, Oltramari JD. Efeito de um programa de treinamento utilizando o método Pilates na flexibilidade de atletas juvenis de futsal. Rev Bras Med Esporte. 2007;13(4):222-6.

19. Chertman C, Santos, HMC, Pires L, Wajchenberg M, Martins DE, Puertas EB. Estudo comparativo do arco de movimento da coluna lombar em indivíduos praticantes e não praticantes de esporte. Rev Bras Ortop. 2010;45(4):389-94.

20. Vieira WHB, Valente RZ, Andrusaitis FR, Greve JMA, Brasileiro JS. Efeito de duas técnicas de alongamento muscular dos isquiotibiais na amplitude de extensão ativa do joelho e no pico de torque. Rev Bras Fisioter. 2005;9(1):71-6.

21. Wells KF, Dillon EK. The sit and reach: a test of back and leg flexibility. Res Q Exerc Sport. 1952;23:115-8.

22. Mallmann JS, Moesch J, Tomé T, Vieira L, Ciqueleiro RT, Bertolini GRF. Comparação entre o efeito imediato e agudo de três protocolos de alongamento dos músculos isquiotibiais e paravertebrais. Rev Bras Clin Med. 2011;9(5):354-9.

23. Ten Berge SR, Halbertsma JP, Maathuis PG, Verheij NP, Dijkstra PU, Maathuis KG. Reliability of popliteal angle measurement: a study in cerebral palsy patients and healthy controls. J Pediatr Orthop. 2007;27(6):648-52.

24. Hui SC, Yuen PY, Morrow JR Jr., Jackson AW. Comparison of the criterion-related validity of sit-and-reach tests with and without limb length adjustment in Asian adults. Res Q Exerc Sport.1999;70(4):401-6.
25. Patterson P, Wiksten DL, Ray L, Flanders C, Sanphy D. The validity and reliability of the back saver sit-andreach test in middle school girls and boys. Res Q Exerc Sport. 1996;67(4):448-51.

26. Alcântara MA, Firmino FR, Lage RF. Efeitos agudos do alongamento: uma comparação entre as técnicas de facilitação neuromuscular proprioceptiva e energia muscular. R Bras Ci e Mov. 2010;18(3):35-42.

27. Mortari DM, Mânica AP, Pimentel GL. Efeitos da crioterapia e facilitação neuromuscular proprioceptiva sobre a força muscular nas musculaturas flexora e extensora de joelho. Fisioter Pesqui. 2009;16(4):329-34.

28. Busarello FO, Souza FT, Paula GF, Vieira L, Nakayama GK, Bertolini GRF. Ganho de extensibilidade dos músculos isquiotibiais comparando o alongamento estático associado ou não à crioterapia. Fisioter Mov. 2011;24(2):247-54.

29. Costa UA, Cronemberger CD, Luz MPM, Portela TS, Matos LKLB. Estudo comparativo de duas técnicas de alongamento muscular: FNP (manter-relaxar) e passivo manual na flexibilidade dos músculos isquiotibiais. Ter Man. 2008;6(26):218-22.

30. O'Hora J, Cartwright A, Wade CD, Hough, AD, Shum GL. Efficacy of static stretching and proprioceptive neuromuscular facilitation stretch on hamstrings length after a single session. J Strength Cond Res. 2011;25(6):1586-91.

31. Neves LMS, Marcolino AM, Prado RP, Pinfildi, CE, Barbosa RI, Furumoto MA. Flexibilidade dos músculos isquiotibiais em dois diferentes programas de alongamento estático. J Health Sci Inst. 2012;30(1):79-83.

32. Tirloni AT, Belchior ACG, Carvalho PTC, Reis F. Efeito de diferentes tempos de alongamento na flexibilidade da musculatura posterior da coxa. Fisioter Pesqui. 2008;15(1):47-52.

33. Marques AP, Vasconcelos AAP, Cabral CMN, Sacco ICN. Effect of frequency of static stretching on flexibility, hamstring tightness and electromyographic activity. Braz J Med Biol Res. 2009;42(10):949-53.

Received: $12 / 03 / 2013$

Recebido: 03/12/2013

Approved: 05/18/2014

Aprovado: 18/05/2014 